\title{
ТЕРМОГРАФІЧНИЙ МЕТОД ДІАГНОСТИКИ ТА ОЦІНКИ ЕФЕКТИВНОСТІ РОБОТИ УСТАНОВОК ДЛЯ ПРОМЕНЕВОГО ЗНЕЗАРАЖЕННЯ ВОДИ
}

\author{
Донець Станіслав Євгенович, \\ кандидат технічних наук, старший науковий співробітник, \\ Інститут електрофізики і радіаційних технологій НАН України \\ ORCID: 0000-0002-1258-1434, \\ e-mail: s.j.donets@gmail.com
}

Литвиненко Володимир Вікторович, доктор технічних наук, старший науковий співробітник, директор, Інститут електрофізики і радіаційних технологій НАН України ORCID: 0000-0003-4850-2555, e-mail: vvlytvynenko@ukr.net

Прохоренко Євген Михайлович, доктор технічних наук, старший науковий співробітник, провідний науковий співробітник Інститут електрофізики і радіаційних технологій НАН України ORCID: 0000-0002-6589-7424, e-mail: forshad58@gmail.com

Розелянуто підходи до оцінки ефективності застосування установок для знезараження води в умовах несталих значень ії оптичної прозорості. Запропоновано розрахункову методику для визначення розподілу дози опромінення в камері обробки. Пропонується застосовувати термографрічні методи до оцінки ефекктивності опромінення води з урахуванням виникнення ламінарних потоків в камері. Запропоновано метод обробки термографбічних зображень з метою автоматизованого виділення ділянок з відмінними значення радіаційної температури та визначення якості та надійності з'єднань.

Ключові слова: термограффічний неруйнівний контроль, розподіл дози, цілісність з'єднань, знезараження води.

DOI: https://doi.org/10.32845/msnau.2021.1.1

\section{Вступ}

На теперішній час в агропромисловому комплексі набувають поширення органічні технології, які передбачають скорочення використання хімічних реагентів в виробничих процесах. 3 іншого боку спалахи епідемій в тваринництві ставлять більш жорсткі вимоги до дотримання санітарно-епідеміологічних норм. Істотним середовищем передачі інфекцій $€$ вода, що споживається як компонент харчування. Серед технологій знезараження води відомими є хлорування, озонування а також обробка бактерицидними ультрафіолетовими (УФ) променями [1]. Спосіб знезараження УФ променями за певними параметрами $є$ більш простий в експлуатації, оскільки не потребує додаткових заходів хімічної безпеки, порівняно 3 хлоруванням та озонуванням. Слід зазначити, що до його недоліків відносять суттєву залежність ефективності обробки від оптичної прозорості води а також ймовірність недоопромінення води в більш віддалених від джерел випромінювання зонах камери обробки. Слід зазначити, що підвищення вимог щодо дотримання бактеріологічної безпеки відкриває більш широкі перспективи оснащення установками для знезараження води УФ випромінюванням великих комплексів з вирощування худоби. Це в свою чергу висуває підвищені вимоги до ефективності знезараження, яка реалізується перш за рахунок опромінення елементарного об'єму води встановленою дозою бактерицидного ультрафіолету.

\section{Аналіз публікацій}

Технологія знезараження води бактерицидним УФ випромінюванням має майже сімдесятирічну історію. Свого часу вона не набула широкого поширення через відсутність тоді стало працюючих джерел випромінювання. Але разом з тим на ранніх стадіях створення принципів проектування установок [2] одна з ключових задач полягала в оцінці рівномірності передачі заданого значення дози опромінення в процесів проходження через камеру з джерелами УФ випромінювання. Так в работі [2] описано підхід, що грунтується на застосуванні натурної моделі камери обробки, виготовленої з оптично прозорого матеріалу, що дозволяє спостерігати за перемішуванням забарвленої пігментом води, яку в певний момент часу подають на вхід в камеру, i, таким чином, оцінювати траєкторію елементарного об'єму рідини і відповідно одержану ним дозу опромінення. Беручи до уваги, що в теперішній час різноманітними виробниками виготовляється широка номенклатура установок, які оснащені додатковими турбулізаторами для перемішування води з метою ії більш однорідного опромінення, проведення подібних натурних випробувань тягне істотні додаткові витрати ресурсів і часу на впровадження нових моделей. До того ж наявність шорсткостей поверхні у реальних виробів буде також впливати на режими перемішування рідини, і, таким чином, вони будуть відрізнятися від тих, що здобуто при модельному експерименті.

Важливим завданням $€$ також оцінка надійності зварних швів виробів, рівномірності затягування болтів на фланцевих з'єднаннях. Вказана проблема зазвичай завдання вирішується проведенням обов'язкових гідравлічних випробувань, що зводяться до констатації цілісності конструкції і ії мі- 
цності при подачі нормативного навантаження. Однак ці випробування не здатні оцінити ділянки найбільш ймовірного порушення в майбутньому при закінченні терміну експлуатацiї.

Нами в роботі [3] було запропоновано термографрічний спосіб оцінки ефективності перемішування води, який полягав в поступовій подачі води з більш високою температурою та наступною реєстрацією розподілу радіаційної температури на поверхні камери. Ділянки з найбільш швидкою зміною температури означають $є$ ознакою Цей метод знаходить все більш широке застосування в науці, медицині, комунальному господарстві, екології, енергетиці [4-7] і його інтеграція в технології оцінки ефективності роботи апаратів для (УФ) знезараження води $є$, безсумнівно, актуальною.

\section{Мета роботи.}

Метою роботи є удосконалення методу проведення термографічного контролю шляхом застосування додаткового програмного забезпечення для обробки карт розподілу поля радіаційної температури на поверхні камери знезараження. Для вирішення задачі використання термографічних вимірювань в підвищенні ефективності діагностики при стендових випробуваннях апаратів УФ знезараження води було необхідним: провести апробацію методу з використанням стандартного програмного забезпечення, яким комплектується прилад; розробити метод сегментації одержаних термографрічних полів для подальшої оцінки рівномірності обробки води; відпрацювати техніку проведення вимірювань; провести апробацію методу щодо можливості ідентифікації прояву можливих дефектів корпусу камери обробки в полі радіаційної температури.

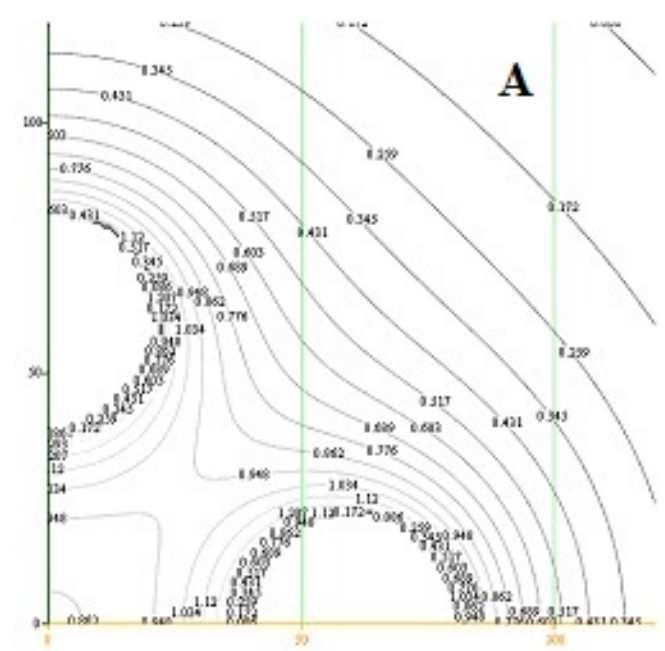

$\mathbf{D}$

Рис.1 - Ізолінії розподілу дози УФ випромінювання в перетині камери з 4- джерел: А - для значення $\alpha=0,15$, Б - для значення $\alpha=0,55$

Існуючі підходи до оцінки дози за середнім показником або за найгіршим виправданий для обробки води з невисоким значенням коефіцієнту поглинання випромінювання (0,1-0,2 см-1), що є - характерними для води з підземних джерел. Проєктування установок для обробки вод з поверхневих джерел або стічних вод (як правило, обсяг обробки 100 м³/год і більше) пов'язане з вирішенням усіх вищезгаданих вимог, причому їх виконання може бути взаємовиключним. Напри-

\section{Методика розрахунку розподілу знезаражуючої} дози.

Умовою інактивації бактеріальної мікрофрлори і забезпечення обробки рідини значенням дози не менше певного значення. За умови використання декількох джерел УФ випромінювання доза буде розподілятись нерівномірно, але при проектуванні необхідно забезпечувати мінімально встановлене опромінення в любій ділянці камери обробки. Серед чинників, що впливають на нерівномірність розподілу дози $є$ те, що інтенсивність потоку променевої енергії по мірі відділення від джерела циліндричної форми змінюється по закону Ламберта-Бугера

$$
I=\frac{I_{0}}{2 \pi r} e^{-\alpha r}
$$

де $I_{0}$ - інтенсивність потоку випромінювання на поверхні, джерела, мкВт/см²; см-1; $r$ - відстань від вісі джерела, $\alpha$ коефіцієнт поглинання рідини. Згідно даних наведених в $[1,2]$ $\alpha$ є складеною величиною, яка визначається емпіричним виразом

$$
\alpha=\frac{K+\Pi+10\left(C_{F e}-0,1\right)}{100},
$$

де $K$ - кольоровість води, град; П-емпірична величина, що враховує мутність води та дорівнює 7 для вод 3 кольоровістюдо 20 град та 9 для вод кольоровістю $20 . .50$ град; $\mathrm{C}_{\mathrm{Fe}}-$ концентрація заліза, мг/л. На рис. 1 зображено результат розрахунку розподілу дози УФ випромінювання для камери, що містить чотири вісьосиметрично розташованих джерела УФ випромінювання.

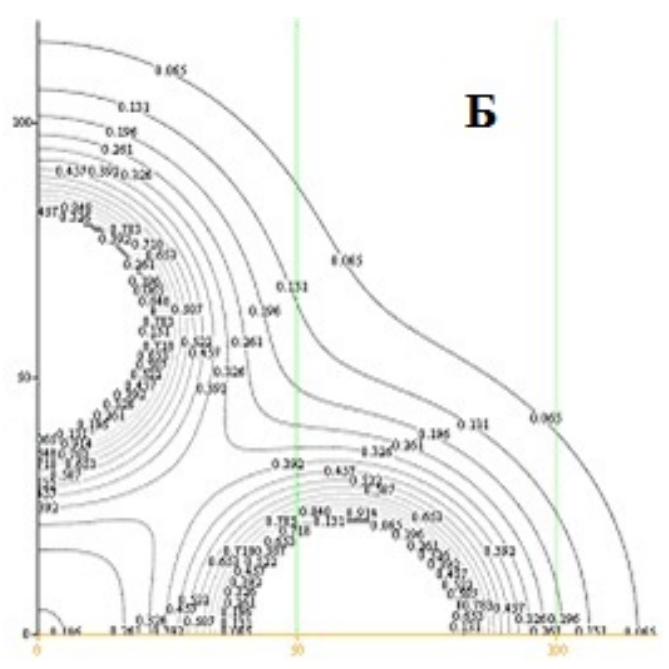

D

клад, нерівномірність опромінення знижується за рахунок установки турбулізаторов, які в свою чергу збільшують гідродинамічні втрати в мережі [8].

\section{Експеримент та аналіз результатів.}

Для випробувань можливості реалізації запропонованої методики були обрані установки продуктивність 20 м3/год та і 1 м³/год відповідно. Для проведення вимірювань температурного поля застосовувався тепловізор Fluke Ti32, що має такі характеристики: тип приймача випромінювання матриця 
320×240 в фокальній площині, неохолоджуваний мікроболометр; теплова чутливість $\leq 0,05^{\circ} \mathrm{C}$; спектральний діапазон ІЧ від 7,5 до 14 мкм.

Оскільки камери виготовлені з нержавіючої сталі, для якої є властивим високе значення коефіцієнт відбиття 14 вимірювання проводили в умовах відсутності предметів, що мають більш високу температуру аніж вода всередині камери також застосовували поверхнве зволоження для зниження коефіцієнту відбиття. Камеру установок заповнювали водою, що має температуру на 30 К вище температури навколишнього середовища. Різниця температур створювала тепловий потік через стінки камери, що давало можливість для температурного прояви можливих дефектів в місці зварних швів. На рисунках 2 і 3 показано розподіл температури уздовж ліній, проведених по корпусу камери в околі зварного шва. Як видно з термограм, температура швів $є$ достатньо рівномірною, при цьому у верхній частині простежується межа заповнення камери підігрітою водою. Очевидно, що перевага термографічного контролю полягає в оперативності виявлення місць можливого стоншення або утворення хімічного або біологічного осаду на стінках камери. Разом з тим для відокремлення температурних аномалій зумовлених особливостями стану поверхні камери від аномалій, що набуті з часом доцільно мати задокументований температурний файл. Для цього на додаток до стандартного програмного забезпечення доцільно застосувати авторські програмні продукти на основі сегментації зображень [9-12]. Сегментація термографічного зображення $€$ необхідною складовою аналізу термограми, оскільки дозволяє виділити області з відмінними зна-

ченнями коефіцієнта випромінювання. Сегментація термограми може здійснюватись декількома методами, причому 3 огляду на те, що значення коефіцієнту випромінювання може бути виідмінним в межах однорідної ділянки досліджуваного об'єкту, наприклад, ділянки з різними видами покриття грунту, або покриття трубопроводу з захисним шаром, що має різні строки давності, необхідно встановити чисельний поріг ступеню деталізації [9]. Тобто сегментацію слід зупинити, коли певні області вже виділені та оконтурені. Складнішою $є$ процедура сегментації складних зображень. Точність сегментації в великій мірі визначає успіх подальших процедур аналізу обробки термограм. 3 огляду на це важливим є забезпечення надійності первинної сегментації.

Алгоритми сегментації монохромних зображень грунтуються на одній з двох базових властивостей поля зображення - розривності та однорідності [10-12]. В першому випадку підхід полягає в розбитті зображення на частини, виходячи з різких перепадів яскравості, що спостерігаються на границях об'єктів. Друга група методів ділить зображення на області, які є однорідними в межах напередзаданих критеріїв. Зазначимо, що межі яскравості на тепловізійному знімку не завжди співпадають з межами яскравості на відеозображенні. I для нашого випадку, коли ми сегментуємо області з відмінним коефіцієнтом випромінювання, доцільно працювати 3 данними відеодіапазону та переносити результати сегментації на теплову матрицю.

Функції перетворення зображень, що засновані на інформації, яка одержується з гістограм яскравості зображень, відіграють ключову роль при вирішенні задач покращення зображень, їх стискання, сегментації та опису.

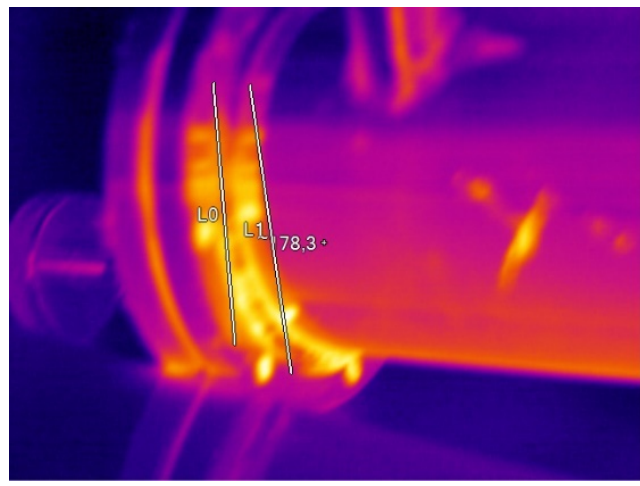

a)

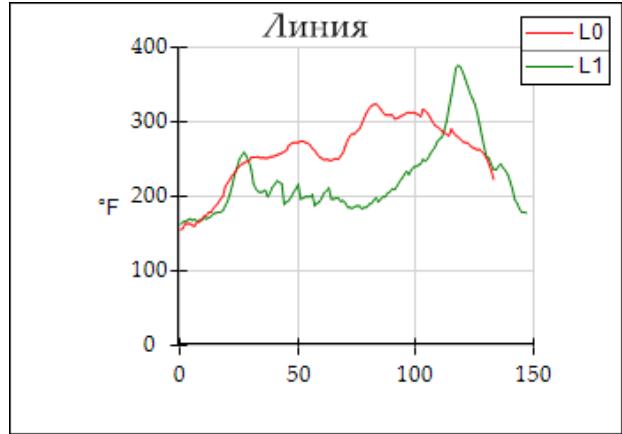

б)
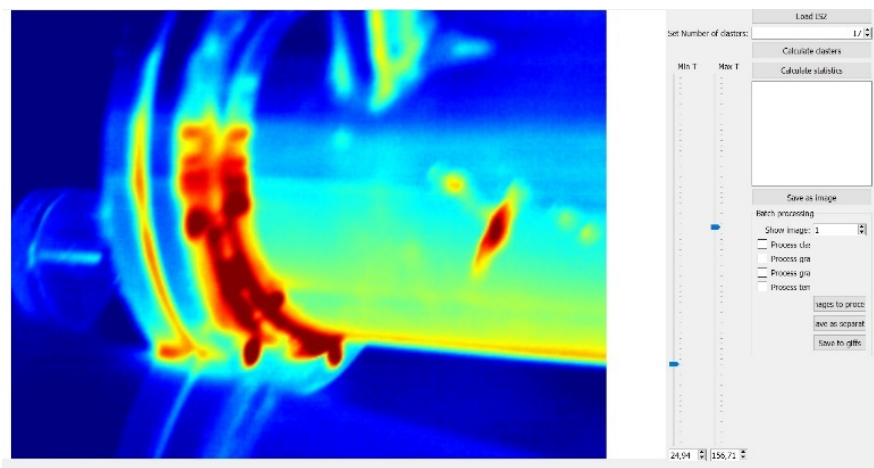

B)

Рис.2 - Розподіл температури в зоні зварного шву корпус-фланец: а) термограма зварювального шву установки, оброблена стандартною програмою; б) профілі радіаційної температури вздовж виділених ліній; в) термограма після сегментації.

Вісник Сумського національного аграрного університету 


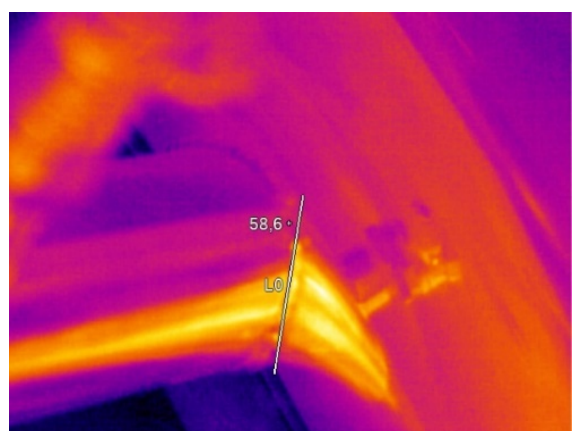

a)

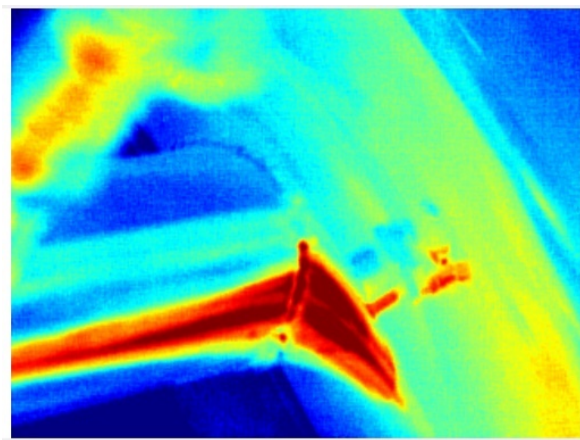

B)

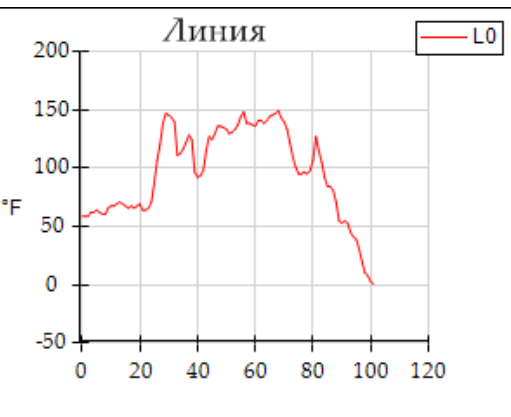

б)

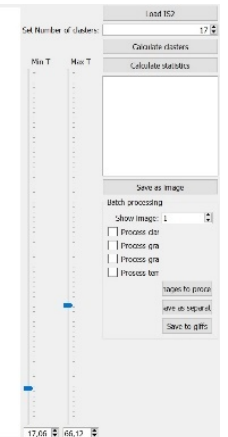

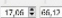

Рис. 3 - Розподіл температури в зоні зварного шву корпус-вихідний патрубок: а) термограма зварного шву установки, оброблена стандартною програмою; б) профілі радіаційної температури вздовж виділених ліній; в) термограма після сегментації

На рис. 4 наведені термограмми, на яких видно ущільнення фоланцевих з'єднань і місць герметизації посадочних

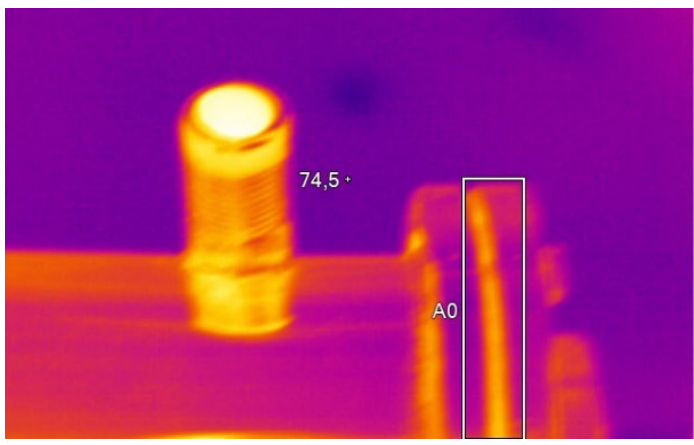

a)

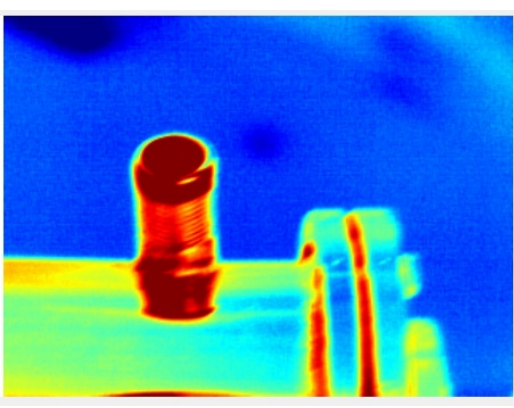

B) місць кварцових цоколів. Рівномірний розподіл температурного поле підтверджує однорідність ущільнення.

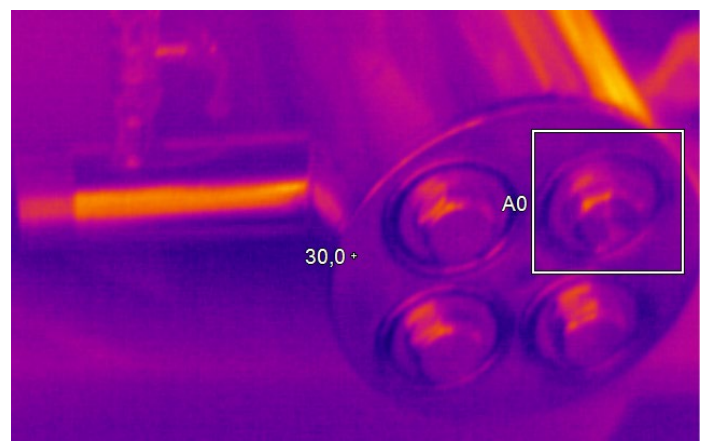

б)
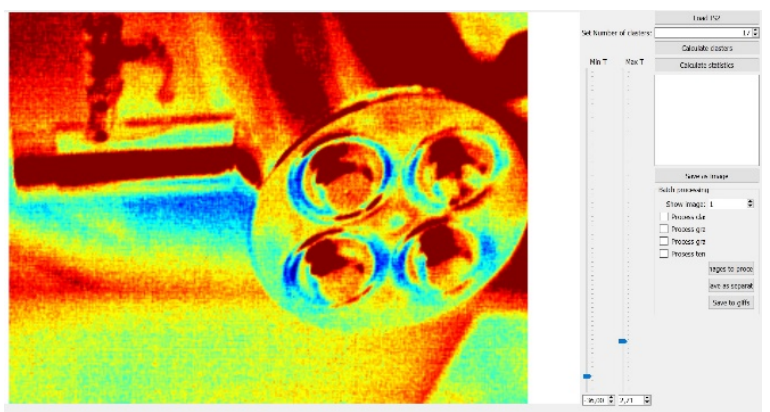

г)

Рис. 4 - Розподіл температури в зоні фланцевого з'єднання: а) Зображення з застосуванням стандартного програмного забезпечення; в) зображення з застосуванням методу сегментації.

Розподіл температури в околі кріплення цоколів випромінювачів; б) Зображення з застосуванням стандартного програмного забезпечення; г) - зображення з застосуванням методу сегментації 


\section{Висновки}

Метод термографрічного контролю і діагностики установок для ультрафіолетового знезараження води дозволяє: - контролювати якість зварних швів корпусних елементів 3 нержавіючої сталі, виявляти можливі тріщини і області несуцільностей зварювальних швів а також якості прокладок ущільнювачів, штуцерів, місць посадки власників вимірювальних приладів.

- контролювати якість фрланцевих з'єднань, виявляти зони розгерметизації і мікровитоків;

- контролювати тепловий режим і розподіл інтенсивності джерел ультрафріолетового випромінювання безпосередньо в процесі роботи установок;

- на етапі конструювання нових установок для ультрафріолетового знезараження води оптимізувати гідравлічну, теплову та бактерицидну схеми камери опромінення, підвищувати техніко-економічні показники установок.

\section{Список використаної літератури.}

1. Г.И.Николадце, Д.М.Минц, А.А.Кастальский / Подготовка воды для питьевого и промышленного водоснабжения .М.Высшая школа.-1984.-368 с.

2. Соколов В. Ф. Обеззараживание воды бактерицидными лучами. 2-е изд. перераб. и доп. М., 1964.-234.с

3. С.Е.Донец, В.Ф.Клепиков, В.В. Литвиненко, С.Н. Шаляпин / Термографический контроль установок для лучевого обеззараживания воды промышленных потребителей // Журнал фрізики та інженерії поверхні.- 2018, том 3, № 3, с..100-105

4.В.Ф.Клепиков, Е.М.Прохоренко, В.В. Колесникова, А.И.Морозов Тепловизионная диагностика для контроля поверхности противотеплового оборудования // Восточно-европейский журнал передовых технологий.-№2/6(50).-2011.-с.65-68.

5. В.В.Брюховецкий, Н.И.Базалеев, В.Ф.Клепиков, В.В. Литвиненко / Тепловизионная акустотермографическая десектоскопия конструкционных материалов // Вопросы атомной науки и техники.-№2(72) вып.97.-2011.с.178-185

6. Н.И. Базалєєв, Б.Б.Бандурян, В.В.Брюховецький, В.Ф.Клепіков, В.В.Литвиненко. Концепція розвитку неруйнівних методів контролю енергетичного обладнання АЕС на основі кореляційної ІЧ-радіометрії // Восточно-европейский журнал передовых технологий. - 2008. - №4/5(34). - С. 10-16.

7. Н.И.Базалеев, Б.Б.Бандурян, В.Ф.Клепиков, В.В.Литвиненко. Тепловизионный мониторинг технического состояния компрессорного и энергетического оборудования как метод эффективного решения проблемы энергосбережения.//Компрессорное и энергетическое машиностроение.-№1(3).- 2006.-с.60-65.

8.Н.И.Базалеев, В.Ф.Клепиков, В.В.Литвиненко, С.Н.Шаляпин Электрофизические лучевые технологии: новая концепция обеззараживания воды ультраффиолетовыми лучами./ Наука та інновації.-2005.- т.1.,№1.-с.99-109.

9. Е.М.Прохоренко, В.Ф. Клепиков, С.Е.Донец и др. / Изменение термопроявлений дефректов материалов и электрооборудования в условиях воздействия климатических факторов // Вісник НТУ ХПІ Сер. «Нові рішення в сучасних технологіях».-№26 (1069).-2014.-с.178-186

10. Vincent L. Watersheds in digital spaces: an efficient algorithm based on immersion simulations / L. Vincent, P. Soille // IEEE Trans. Pattern Analysis and Machine Intelligence. — Vol. 13, № 6. - 1991. - P. 583-598

11. Pratt W.K. Digital image processing: PIKS scientific inside / W.K. Pratt. - John Wiley \& Sons, 2007. - 782 p.

12. Haris K. Hybrid image segmentation using watersheds and fast region merging / [K. Haris, S.N. Efstratiadis, N. Maglaveras et al.] // IEEE Trans. Image Processing. — Vol. 7, № 12. — 1998. — P. 1684-1699

Donets S.Ye., Institute of Electrophysics and Radiation Technologies NAS of Ukraine

Prokhorenko E.M., Institute of Electrophysics and Radiation Technologies NAS of Ukraine

Lytvynenko V.V., Institute of Electrophysics and Radiation Technologies NAS of Ukraine

Thermographic method for diagnosis and estimation the efficiency of installations for uv ray disinfection of water

Approaches to evaluation of efficiency of application of installations for water disinfection in the conditions of unstable values of its optical transparency are considered. A calculation technique for determining the radiation dose distribution in the treatment chamber is proposed. It is proposed to use thermography methods to assess the effectiveness of irradiation of water, taking into account the occurrence of laminar flows in the chamber. A method of processing thermography images for the purpose of automated selection of areas with different values of radiation temperature and determining the quality and reliability of connections is proposed.

Key words: thermographic non-destructive testing, dose distribution, integrity of connections, water disinfection.

Дата надходження до редакції: 23.01.2021 